\title{
MARI AND MARIE: PERFORMATIVITY AND CREATIVITY OF TWO ESTONIAN SINGERS IN THE LATE NINETEENTH CENTURY
}

\author{
Janika Oras
}

\begin{abstract}
One of the results of the rapid modernisation of Estonian society in the second half of the nineteenth century was the change in singing culture: the older singing style, regilaul, which represents the Kalevala-metric song tradition, was gradually replaced by the newer end-rhymed singing style. The article analyses this change by focusing on the performances of two female singers from central Estonia, representatives of different generations. The main research sources are folklore texts and memoirs written down by the younger singer Marie Sepp, featuring, among others, a female singer from the previous generation, Mari Pärtens. The performativity of the singers is displayed in a cross-section of the changing performance arenas and registers which are related either to the older or the newer singing style. The article discusses the individuality of the two singers, as well as manifestations of gender, age, artistic creativity, and the historical socio-cultural context in their performativity.
\end{abstract}

Keywords: anthropology of aging, Estonian regilaul, Kalevala-metric poetry, modernisation, oral tradition, newer end-rhymed song, performance registers, performativity, female singers

I wrote down the old singing games that we played all the time when I was a young girl. Boasting is usually frowned upon but I'm telling you that I was one of the better players - the games were always great when I took part. Also, other girls came to learn from me. ${ }^{1}$

If gentlemen from town had come to Purtsi at the moment when humans were on their all fours, barking like dogs, they would have thought they were at a madhouse. But aunt ['Vainu Aunt', Mari Pärtens] showed us that sons of Adam used to do that, and so did we. But nobody could do headstands; we all yielded a pawn instead. ${ }^{2}$

The opening quotations describe the playing of singing games in a village in central Estonia in the second half of the nineteenth century. This was a time 
of dramatic socio-cultural changes in Estonian society, with modernisation being the common denominator (Jansen 2004; North 2015; Valk 2004, 2014; Vunder 2001, 2008). The changes in society also brought about a turn in the singing culture: the older oral singing culture was being replaced by a newer, semi-written singing culture with different themes and poetics. ${ }^{3}$ The quotations focus on two singers - Marie Sepp, who wrote down the quoted texts, and Mari Pärtens, an elderly woman, who played singing games with the young. Despite my previous acquaintance with extensive studies on the emergence of a new singing culture, only after reading Marie Sepp's manuscripts I realised the magnificence of the coming of the new singing style and the importance of singing games for the young people of the late nineteenth century - the realisation was so vivid as if I had been there myself.

The aim of this article is to get closer to understanding the turn in the singing culture through the singing experience of two women - Marie Sepp and Mari Pärtens. The approach focuses on the differences in the performativity of the singers representing different generations. One of the main issues is how these differences reflect the changes in cultural performances brought forth by the transition from the oral culture to modern written culture. Next to shedding light on the cultural processes, I have chosen to focus on the individuality of a singer as a creative person and on how a singer's self-performance relates to her living environment, social status, gender, and age.

It is inevitable in dealing with historical material that knowledge about the live performances and experiences of the past reaches us by mediation, as written representations. The elaboration of the topic here was inspired by the nearly 500 pages of texts written down by Marie Sepp and constituting the main bulk of the archival materials associated with these two women. ${ }^{4}$ While Mari Pärtens did not write down folklore, Marie Sepp, and briefly also other folklore collectors, have written about her. This is why the two women are unequally represented in the sources; there is considerably more material on Marie Sepp, and any discussion about specific mediations of an individual singing experience and evaluations of the tradition is based solely on her material.

Marie Sepp's writings differ from the material recorded by instructed folklore collectors, and thus they partly represent an alternative discourse - an uninstructed, voluntary local collector's idea of how to write down oral tradition. It is characteristic of her texts to reflect personal experience, express judgments, mediate specific performances or events; the texts are associatively connected and filled with details, thus making them more similar to a spontaneous oral performance. ${ }^{5}$ Owing to these specific features, which are often found incorrect or undesirable from the perspective of historical folklore studies (Kurki 2004; Mikkola 2013: 155), the texts by Marie Sepp offer at least some answers to the 
research questions posed here. Marie's retrospective view is written from the position of a mature woman who relives the past and mediates it in a very direct and personal manner. It seems as if Marie has 'forgotten' during writing that the addressee of her texts is an anonymous archive user - they rather seem to be addressed personally to August Pulst, who worked at the Tallinn Theatre and Music Museum and with whom Marie had developed a close relationship.

Even though the material on the two women is inherently sporadic and fragmentary, it hides telling details about the women's individual singing worlds. Studies on microhistory, oral history, and anthropology have shown that focusing on individual experience conveys unique information about culture, one that is equal to generalisations (Burke 1991; Hellier 2013; Jackson 2005: xi-xii; Ruskin \& Rice 2012; Smith \& Watson 2001). I am drawn to American anthropologist Lila Abu-Lughod's idea of "writing against culture" - of a particular cultural description that focuses on individual cases to give an adequate picture of reality (Abu-Lughod 1991, 1999: xvii-xviii; cf. Jackson 1996: 8).

Bearing in mind the transformation of one singing style to another and the theme of social change on the background, the observation of the performativity of individual singers provides an opportunity to identify the internal multivocality of the transformation processes, the dialogue of different ways of thinking and creating (cf. Mikkola 2009). The individual-centred observation serves yet another important function: it establishes a personal emotional relationship with the research subject and gives the reader a chance to 'recognise' the experiences of a person who lived in the past, relying on his or her own experiences (Vilkko 1997: 185-187; Timonen 2004: 24, 410). The connection established through 'recognition' could alter the relationship between the individual and culture under study and pave the way to new knowledge: "recognition as recognition, that is, as the mobilization /.../ of memories that are at the core of personal identity, seems to be the cutting edge in relations with others that have a chance of producing knowledge" (Fabian 2001: 177).

The central keywords in the article are performance and performativity. The meaning of these concepts differs in the theatrical and linguistic approach to performativity, being either founded on a conscious role-play, staging, or on the identity that is reshaped by reiterating patterns of social behaviour, respectively (see, e.g., Schechner 1988; Phelan 1993; Butler 1990, 1993). In anthropological research these meanings have been combined since it gives an opportunity to approach identity construction from different angles and in different situations (Friedman 2002: 5). It seems that in the cultural performances both the unconscious following of cultural patterns and a conscious shaping of an individual singer identity are combined (Spiller 2010, 2014). 
During cultural performances the performer is in a special, heightened state, which activates his or her potential creativity (Bauman 1992; 2012: 99). Hence, cultural performances give a special opportunity to observe the creativity inherent in the tradition as a dynamic process (Glassie 2003; Cashman \& Mould $\&$ Shukla 2011). Pointing out individual creative solutions of the performers sheds light to the diversity of choices during a traditional performance as well as to the devices of the dynamics of tradition.

Summing up the aforesaid, the focus of the analysis is on cultural performances; these are important from the viewpoint of the research questions and the sources tend to be more informative in this regard. I primarily consider the aspects of performativity of the two women associated with artistic creativity, but also gender and age.

\section{MARI PÄRTENS AND MARIE SEPP: LIFE AND BECOMING} A SINGER

Even though the two singers represent different generations, the divergence in their performativity was not only caused by the differences in singing practices, mentality, and behaviour conditioned by cultural changes. In the following short biographies I will try to highlight the specific circumstances that have influenced the status of these two women as singers, and their individual performativity.

Mari Pärtens (Pertens, Bertens) was born at Purtsi (Eessaare) farm near Kolga-Jaani on 22 July 1832. The memoirs of Mari's niece Rõõt Grauberg and Marie Sepp about the life and people at Purtsi farm as it was a few decades later give some idea of Mari's childhood home. Mari Pärtens' parents Rõõt and Hans Meiel and their offspring were joyous people, had a good sense of humour and were skilled singers, instrument players, and storytellers. The farm was home to an extended family, closer and more distant relatives of many generations, and the help: "They used to have several lodgers in their home, but there was never any quarrel or problem. Only fun and singing." ${ }^{6}$ In the 1870s, Mari's mother, Rõõt Meiel, reportedly had the largest repertoire of regilaul in the parish. 135 song texts recorded from her were published as early as in 1886 in the regilaul anthology Vana Kannel (The Old Psaltery; Hurt 1886). The men of the Purtsi farm were particularly famous for their nonverbal joking skills (Norrick 2004); for example, people reminisced about Mari Pärtens' brother that "whenever he had been drinking, he used to raise his violin to the back of his head, and played and danced and joked around". ${ }^{7}$

Old traditions were preserved and old beliefs were revered longer at Purtsi farm than in the area - members of the family were known to be "great wise- 
men" and "believed in all sorts of superstition". ${ }^{8}$ In the 1880 s young people used to come to Purtsi farm to play the yuletide game "Catching the ruffe", which was associated with ritual magic (Hiiemäe 1998: 278) and was no longer played anywhere else. In this environment Mari Pärtens became familiar with the old tradition and since she could not write, she is first and foremost a representative of oral culture.

Mari got married in 1859, but her husband died a year later. Mari returned from her husband's house to her parents at Purtsi farm to raise her son Jüri there. After her son had got married, Mari moved with him to the sauna of Vainu farm and was thus called Vainu Aunt. Mari was extremely loved and respected in the community - she was a local midwife and a person with exceptional singing skills, ${ }^{9}$ sense of humour, and performing talent, who was welcomed at all events and parties. In the characterisations by the community members the motif of 'joking' keeps recurring, indicating Mari's ability to entertain people with both verbal and nonverbal improvised humour: "a well-known singer and very funny", "she was a funny person", "someone who entertained us all”. When Mari Pärtens died on 18 April 1919, a funeral wreath was placed on her grave. This is a sign of the community's utmost respect, because at the time placing wreaths on the grave was not common among the peasantry.

Marie Sepp was born on 19 December 1862 as the second child into Kai and Hans Kõu's family of seven children. Her father Hans Kõu had served in the Russian tsar's army for 21 years and was the only man in the area to return from the long service. As an army veteran, he was allocated a small farmstead that came to be called Kõue. At a rather young age, Marie had to take over household chores from her sick mother. She had attended school only for eleven weeks and thus her schooling was mainly whatever she learned from her parents and her sister's school textbooks. Like Mari Pärtens, Marie also took from her childhood home fine singing skills and a good sense of humour - her father used to be "always in good humour and funny". Marie's father had seen the world and had become a lower-ranking officer in the army, so from him Marie may have got her go-getting attitude and confidence to talk to people higher up the social hierarchy, whether they be local manor owners, folklore collectors, or the president. ${ }^{10}$

Marie Sepp had quite a different upbringing than Mari Pärtens - she did not grow up in an extended family but in a nuclear family. The greater than average individualist attitudes in Marie's texts may have also been the result of her father's special status and Marie's closer connection with home related to her taking over household responsibilities from her mother.

Another difference, compared to the growing-up environment of Mari Pärtens, was Marie's family's noticeable orientation to literary culture. Books, church 
and secular song repertoire in the Estonian language, the large scale printing of which started at the same time, in the 1850s-1860s, occupied an important place in Marie's recollections. It is possible that the smaller significance of earlier oral tradition resulted from her father's long absence from the peasant environment and her mother's contacts with high culture during her service at the manor.

The years 1879-1886 mark an important period in Marie's life history. During these years, between her receiving confirmation and getting married, she served as a maid at Purtsi farm. Mari Pärtens lived at Purtsi at the time as well. Marie had a chance to sing there together with Mari and her mother Rõõt Meiel, and learn their rich repertoire in the old singing style. ${ }^{11}$ Regilaul, however, was not central in her singing practices. When she was serving as a maid at the farm, she used to sing in the local church choir. This was the most active time of socialising with other young people, which centred around learning and practising newer folk songs, especially singing games.

Marie's love story, in which literacy played a special role, falls to the same period when she worked on Purtsi farm. After his army service, one of Rõõt's grandsons, Kristjan, came to work there as a farmhand - he was known as a fierce worker, but also a fine violin player. The young lovers communicated only through letters and in one of them Marie also received a marriage proposal with an engagement ring. Soon after they had married, they moved to Marie's father's home in Kõue locality. For livelihood they both worked outside home - Marie worked in the field and wove fabrics, Kristjan worked as a builder and did tailoring jobs. Their only son Kristjan was born in 1892.

Marie had had first personal contacts with folklore collectors already in 1906. In 1929, her songs were recorded on a phonograph during fieldwork. However, more active communication with professional folklore collectors and the local correspondent to the archives, Johannes Raidla, took place in the 1930s. Marie started to write down folklore after her husband died in 1930. First the writing served as a therapeutic activity: "I was alone in the house and I cried so much that I could hardly see. Then I started writing down riddles. Whatever I could remember I wrote down, until it was quite a long text" (ETMM, MO 237: 1/34: 11). ${ }^{12}$ The main part of Marie's folklore texts were written down and sent to the Tallinn Theatre and Music Museum after recording her regilaul songs in Tallinn in 1937, upon the request of August Pulst, one of the organisers of the recording. Marie died on 19 April 1943. 


\section{MARI AND MARIE AS SINGERS: PERFORMATIVITY AND PERFORMANCE SITUATIONS}

Information about the performances of Mari Pärtens and Marie Sepp mainly concerns the period between the 1870s and 1890s, to some extent also the first decade of the twentieth century. Young Marie and Mari, who was at a mature age at the time, sang together quite much. Their roles and manner of performativity, also their preference of performance situations demonstrate idiosyncrasies and individual differences even in the limited material available about them. Their repertoire cannot be compared, because only 20 songs of mainly older singing style of Mari Pärtens have been written down, while the number of songs sung by Marie Sepp is 249, of which 104 are in the older singing style and 145 in the newer style (double recordings of the same songs included). In the following I will observe the performances of the two women, tracing the performance situations and registers mentioned in the sources. ${ }^{13}$ Since the descriptions focusing either on situations related to regilaul or the newer folk songs are easily distinguishable in Marie Sepp's texts, I have structured the current analysis around that. Still, it has to be borne in mind that, in reality, songs of the older and the newer singing style could be heard in the same performance situations.

\section{Older singing style, regilaul}

While the second half of the nineteenth century saw the rapid disappearance of regilaul in most of Estonia, the older singing style survived longer in KolgaJaani parish - even compared to its close surroundings such as the northern parts of Tartu and Viljandi counties. Perhaps one reason for that was the parish's relatively remote location ${ }^{14}$ and the sparse settlement on bog islands, as well as poor economic situation, which made the peasantry less stratified and the community more unified. In the writings of Marie Sepp and elsewhere, the most frequent performance situations of regilaul were singing at weddings and during harvesting crops. Wedding and harvesting songs were the central genres in Estonian regilaul tradition (Tampere 1956; 1976: 111). In Kolga-Jaani parish they were quite often sung in traditional situations well into the $1920 \mathrm{~s}$.

Sources describe the performativity of Mari Pärtens and Marie Sepp in wedding situations in rather different terms. Mari Pärtens leaves the impression of a powerful and influential wedding singer, and a ritual leader of the oral tradition. In the earlier tradition, a wedding singer had a special role as the 'voice' of the family and a ritual leader, whose singing marked all the important 
rituals and upheld the heightened level of energy during the ritual situation. The descriptions from Kolga-Jaani parish highlight the singers' physical activity and their powerful singing voice:

The women were wearing silver coins around the neck, so that their necks were all bruised after the wedding. The coins were heavy and all the jumping and stomping bruised their necks.

When there were good wedding singers in the family, singing at a summer wedding could be heard at the distance of 5 to 6 versts. (ERA II 141, 108, $388)^{15}$

The latter text also mentions Mari Pärtens.

Mari as a traditional wedding singer of the older generation was proficient in the art of verbal duelling and performed traditional mocking songs at the wedding. According to the descriptions from the late nineteenth century, the mocking songs - or, more specifically, the part that involves the offensive songs insulting other singers - in Kolga-Jaani belonged to the repertoire of men and older female singers: "Young women didn't sing along to the more obscene songs. There was no match for older women in that. They knew and understood more and they were not afraid or embarrassed" (ERA II 141, 108). Mari Pärtens, in particular, was characterised as such an elderly, strongly assertive singer: "The older female wedding singers /.../ shut everybody else down. They became so obscene when they couldn't overcome the other singer or once they got angry. Rõõt (Meiel) of Purtsi and Vainu Aunt (Pärtens) were the fiercest" (ERA II 141, 388).

Marie Sepp never called herself a wedding singer, nor has anyone else called her that. At the same time, in a questionnaire filled in during a recording session, Marie said that wedding songs were her favourite genre and to the question where she used to perform with these songs she replied: "At communal work, at weddings" (ETMM, MO 237: 1/34: 4). ${ }^{16}$ The wedding song texts written down by Marie in 1938 seem to reflect her personal singing practices. Her verses are partly improvisational and display significant influences of the newer singing style. Yet they are not very different from the other later recordings; since in Kolga-Jaani wedding singing was actively practised even as late as in the twentieth century, the tradition continued to adapt to the newer way of thinking and poetics.

In the fragmentary information available about Mari and Marie, one could see reflections of the changes in the status of wedding singers and the loss of the ritual function of the wedding song in the period of modernisation. The age difference of the two women also plays some part here. It is known that in the 
earlier tradition the wedding singers used to be married women (Tedre 1973: 106). The qualities of a good singer were extensive singing experience, courage to perform, and confidence, also fewer family responsibilities. ${ }^{17}$ These qualities are mainly associated with older women (Kalkun 2010: 15; Silver 2003; Vakimo 2001: 45-46). However, in Kolga-Jaani parish in the second half of the nineteenth century wedding songs were sung by people of all ages and genders, whereas the lead or solo singers at weddings were usually older women.

The peak of Mari Pärtens' wedding singing career coincides with the period when the wedding singing served a ritual function and the singer led the ritual. Rapid cultural changes also brought along the transformation of the wedding ritual. According to Finnish researcher Lotte Tarkka, who has analysed changes in the Kalevala-metric tradition of Viena (Archangel) Karelia, the changes also happened in "singers' ideals and habitus, which determined the choice of performance arenas, the performers' body language and verbal register" (Tarkka 2005: 378). Marie Sepp's best wedding singer's age falls to the early twentieth century, when singers had lost their status as ritual leaders, the old wedding songs were increasingly reduced to a form of nostalgic entertainment, and during important rituals regilaul was being replaced with prayers and church songs (see, e.g., Ounapuu 2003: 55, 67; Anttonen 1987: 5). It appears that Marie's attitudes and performativity were already partly shaped by the new norms of self-discipline and control, restricting spontaneous and 'vulgar' self-expression, typical of traditional wedding singing and verbal duelling in particular (Frykman \& Löfgren 2003 [1987]; Vunder 2008: 464).

The description of communal work ${ }^{18}$ by Marie Sepp, in which she emotionally mediated her personal singing experience (using first person plural), differs from the neutral descriptions of weddings. She does not mention Mari Pärtens in her descriptions, but it is likely that Mari and young Marie worked side by side in the field. The recorded song texts by Mari Pärtens largely coincide with Marie Sepp's texts. The description reveals that Marie Sepp must have been one of the most active singers in the field, enjoying singing in the open space and the freedom of improvisation and immediate communication that regilaul style offered.

Singing in the field did not merely serve the entertaining function; it also supported working, marked the harvesting ritual ${ }^{19}$ and bounding, or 'domesticating', the space with voice. Working in a large group of people on a wide territory introduced the need to maintain contact and feel the sense of togetherness in a common space. Marie's description leaves a vivid impression of a rich soundscape, where voices with different vocal timbres are heard from different places, alternating and sounding together. Evidence of the conscious enriching and enjoying of the soundscape are the shouts added to the songs written 
down from Mari Pärtens with an accompanying remark: “Ooh! Aah! Aah! were the sounds of workers' cheering after the song” (EKS 40, 17/8 (7)). One of the functions of singing was to keep cutters in a steady line in a field. When a part of the line fell behind others, their neighbours started singing and "the song worked, people gathered over there and soon the work order was even again" (ETMM, MO 237: 1/35: 167).

The need to maintain the level of energy required for the work favoured singing in dialogue and the verbal duelling, which created a special state of mind. ${ }^{20}$ Men used to sing insults to each other ("What are you, voiceless, creaking about..."; "What are you, bug, buzzing here...”), and women responded by singing more loudly. "Women were singing beautifully, but men were singing against each other and it got quite heated at times. Then we started singing very loudly, so that they turned quiet or we could no longer hear them" (ETMM, MO 237: 1/35: 167-168).

It is possible that such women's behaviour mirrors the changing of social norms, which was already discussed in connection with weddings. As the mentality changed, the insults containing graphic images of physical intimacy, characteristic of mocking songs, were started to be seen as shameful. At the same time, in premodern culture, the register of insulting songs and using obscenities as well as sexual mockery and humour was first and foremost the domain of older women - at least in public use (see, e.g., Vakimo 2001: 28, 138). In this light, women's attempt to 'quiet' men's insulting songs by producing intense and loud voice represents completely traditional behavioural strategy.

Marie Sepp has mentioned other performance situations of the older singing style very briefly or they are represented only by the song texts. An exception is an account of Shrovetide customs, in which Marie rather opposed the choices of Mari Pärtens and others at Purtsi farm. Marie describes how Mari Pärtens used to carry out customary Shrove Tuesday foretelling and sang a chant-like Shrovetide song before the farm people's traditional ride to the tavern (the ritual purpose of the ride and the related songs were to promote flax growth). Marie did not join others at the tavern and instead went to the schoolhouse to play singing games with children:

Everybody was on their way to the tavern. They harnessed the horses and the sleigh ride to Tässi tavern began, aunt [Mari Pärtens] was singing:

Lähme vastlaliugu laskma,

linad liulaskijale, liugu, laugu,

takud tagant vahtijale, tudrad toas istujale!
Let's take a sleigh ride in Shroveflax for the sliders, tow for those who stay behind, false flax for those who sit at home! 
I was supposed to get tow [for "staying behind"] /... / But I didn't stay at home; I went to the schoolhouse and played singing games with children. At this time there was nowhere else to go but to the tavern; men always went there and on Shrove Tuesday so did women. This happened every year, others went to the tavern and I went to the schoolhouse. (ETMM, MO 237: 1/35: 163)

Another recollection from the Christmas of 1882 is associated with the Shrovetide description. Now Marie also juxtaposes the Purtsi farm chamber with the schoolhouse. After visiting the schoolhouse where the wife of the manor owner handed out Christmas presents, Marie with other young village people arrived at Purtsi farm and sensed the striking contrast between light and darkness:

Do you think it was nice to go back home? I must confess: not at all. There were such bright lights at school, and on the way home there was splinter light, and now you barely had light to not trip over someone. The chamber was filled with lamp and pipe smoke - the farm master and his brotherin-law were serious smokers. (ETMM, MO 237: 1/35: 157)

In her texts, Marie juxtaposes the well-lit schoolhouse with the tavern and Purtsi farm, and here it is possible to look for the symbolic opposition of earlier and newer performance arenas and registers. Marie undoubtedly preferred the newer singing style. I find very telling Marie's comment to a song that she considered the oldest of the songs in her repertoire of the newer singing style, as she knew it already in 1866: "I like the fact that already in those days there was some Estonian who knew how to beautifully create a song" (ERA II 84, 493). It seems that this "creating beautifully" implies a comparison with the older singing style and its poetics. But that still does not automatically mean denial of the older style. Marie's attitudes towards regilaul were rather ambivalent and depended on the context. For her, to some extent, regilaul was already part of the new modern sphere or performance arena represented by urban culture and literacy. The regilaul songs that she wrote down reveal a personal creative relationship with the old ways of expression and her account of communal work reflects the pleasure derived from common regilaul singing.

\section{The newer singing style: Impassioned playing of circle games}

Marie Sepp's and most of Mari Pärtens' activities as singers coincide with the broad dissemination of the newer end-rhymed song. There were many reasons for the gradual withdrawal of regilaul and the spread of the newer end-rhymed song, but perhaps the most essential one is the change in people's way of think- 
ing brought about by social and cultural modernisation (e.g. Tedre 2008: 432). One of the important forms of the newer singing style was the circle game. The relatively well-documented repertoire of Marie Sepp contained 87 different circle games, and only 28 song texts without data about playing them as circle games. It is possible that such proportion was quite common for the repertoires of women who tend to play circle games more actively. Marie Sepp's descriptions of performing the newer singing style, personal performance experiences, and Mari Pärtens as the performer of the new style are associated specifically with circle games.

The popularity of circle games or newer singing games in Estonia peaked from the second half of the nineteenth century to the first half of the twentieth century. The games were played in a circle to the end-rhymed stanzaic singing. According to the way of playing, the circle games could be divided into two major groups: in imitation circle games the players acted out the subject of the song, and in circle games with intermediary dance parts players walked in a circle while singing the verses and danced in alternating couples during the intermediary dance song. The intermediary song for dancing was not part of the main song (Rüütel 1980).

A circle game, as the newer folk song in general, is associated primarily with entertainment. Marie's texts give quite scant information about the performance situations when she and Mari Pärtens used to play circle games. The only clearly marked performance locations are Purtsi farm and the schoolhouse. Purtsi farm was a popular place among the young people of the area, where they gathered on Sundays or during calendar holidays to have fun and learn and play circle games. The schoolhouse, which was close to the farm, was an important location for young Marie during her working at Purtsi. She liked being around schoolchildren: "The children were so familiar with me, the ones who lived further away and didn't go home on Saturdays came to visit me on Sundays, and the game was on again" (ETMM, MO 237: 1/35: 163).

Among the important situations of playing circle games were the dance evenings (called simmanid or, locally, tontarid) of the youth. Marie wrote that she did not attend these parties, and nor did she go to the tavern, St. John's Day's village bonfires, or the village swing. She wrote critically about the drinking and brawling at the tavern and at parties, as well as about young men visiting maidens' sleeping chambers at night. Matti Sarmela has written about the youth culture in Finland in the eighteenth and nineteenth centuries, which represented the society's transformation from family-centred to group-centred integration. An extreme example of that were village fight groups, which were most active in western Finland in 1850-1885 (Sarmela 1974: 106). Some instances of young men's group culture were known also in Estonia (Anepaio 1996: 
150-151; Tampere 1999: 25), and one may speculate that Marie, who preferred the new behavioural norms which spread among the country people during the modernisation period, disliked their aggressive nature. ${ }^{21}$

We may assume that Mari Pärtens did not participate in the young people's parties either. In addition to the gatherings at Purtsi farm, she may have participated in playing circle games at the events for many generations. The archive texts from Kolga-Jaani reveal that circle games were played at many family events - christenings, weddings, also at calendar feast day celebrations, and at communal work, especially the kind that took place inside the house during wintertime and ended with a celebration.

As the opening quotation of the article reveals, circle games were a central genre in Marie Sepp's performance practices. Unlike her descriptions of performing the regilaul, the texts about circle games present her in a leading role - as initiator and lead singer: "the games were always great when I took part" or "the games never stopped when I took part". In her descriptions of playing the games, Marie has mentioned her singing skills. Apart from having a clear voice, she reportedly knew more lyrics than anyone else and probably added or improved song texts herself.

While in the games with the intermediary dance part the main activity was limited to singing, dancing, and choosing a dance partner, then the imitation circle games offered much more creative opportunities for the players. A successful acting cooperation required learning the song's contents, agreeing on the movement, and finding appropriate props. Marie has described the rehearsing of the circle game "Villem and Juuli"22 on Epiphany with the young people visiting Purtsi farm:

We decided to play a singing game and tried how it would play out. At this time, circle games were like plays, following the lyrics of the song. Villem and Juuli were taken to the monastery, had white linen wrapped around them and were taken through the door to the graveyard. These days you had to rehearse playing games. (ETMM, MO 237: 1/35: 161)

Marie's explanation added to the recorded text gives additional information about their 'staging':

A girl and a boy are in the middle of the circle. The boy leaves. The girl falls on the ground. The boy falls next to her. Other girls take the girl away and other boys take the boy. (ERA II 96, 459/61 (23))

The themes of the end-rhymed singing games reflected a completely different mentality compared to the earlier singing game tradition. Their central subject was romantic love, which entered the culture of feelings of Estonian peasantry 
in the nineteenth century. The model of romantic love, which emerged among the European middle class in the seventeenth up to the nineteenth century, combined the model of passionate desire originating in the former feudal culture, and a new type of family ideal - a nuclear family ruled by the husband, where the couple shares emotions and intimacy and the union is not solely determined by the social status. In the agrarian culture, where the main social unit was the farmstead rather than the family, and where marriage functioned mainly as a component of the production process, love becoming a value in marriage and attaching emotional importance to couple relationships signified a completely new way of thinking (Frykman \& Löfgren 2003 [1987]: 92-94; Giddens 1992: 38-47; Roca \& Enguix 2015; Soikkeli 1999). The internationally spread ballad texts that were used in circle games reverberated the different stages of the development of the idea of romantic love: the songs entail the tragically ending opposition to the kin and its control, class conflicts, the all-conquering fidelity, passionate expressions of emotions and eroticism.

Performing circle games as a symbolic activity encouraged the spread and adoption of the new relationship model. Reading Marie's notes leads to a realisation that circle games provided important instruction in life and especially emotions for the young people - they taught which emotions to feel and how to express these. In addition to the games, such 'theoretical' wisdom could also be found in the popular sentimental literature on the same subject (EKA 1966: 128-296; Jansen 2004: 70-71). Next to the tragic plots, some games were clearly didactic, introducing new ideals and behavioural norms through criticism or humour and mockery. The central theme in many circle games is playful choosing of the 'right' partner, whereas the choices are often handled without any consideration: I will not have you, you are no good to me, I will reject you, too, I will have you... It seems that the games were indeed played to practise choosing of a partner based on individual feelings - one characteristic of the nineteenth century youth culture was the individual agency, the ambition to choose the life partner independently from the family (Asplund 2002: 244-255; Niiranen 2013: 111).

Marie's descriptions suggest that, instead of the activity, in the imitation circle games it was more important to identify with and express the feelings of the song character. The games have many static parts where the character's only activity is feeling sad, for example: "A girl is holding a handkerchief in front of her eyes [during the first three verses], and cries until she looks around during the fourth verse" (ETMM, MO 237: 1/35: 88). In the game "Groom, why did you leave me", ${ }^{23}$ the main character, a young maiden, expresses her suffering during nine verses and shames the young man who cheated on her: 
The groom and the maiden are inside the circle, the maiden is singing in front of the man, and making a shaming gesture. The groom is also very timid, stares down at his feet, and does not dare to look up. When singing the last verse ["Now I'm leaving, leaving with tears. Oh, pain, oh, pain, pain in my heart..."], the maiden leaves holding a hand over her heart.

As a typical expression of romantic feelings, the repeated movements in the games were falling on the ground, picking up the fallen person, and kissing in forgiveness. Kissing and frequent holding of hands already falls in the realm of eroticism, which plays an important role in both singing game tradition and newer dance culture (cf. Asplund 2006: 134-135; Niiranen 2013: 234).

Mari Pärtens, who in the 1880 s was at the age of 50-60, took an active part in the young people's singing games, as Marie Sepp mentioned. Archival documents suggest that many outstanding elderly female singers stood out in their age group for being energetic and vital, participating also in the entertainment activities of the young (e.g. Oras 2008: 185). In this context it is worth noting that Marie Sepp also learned singing games even while in her forties, "playing together with younger people", as she put it herself.

To take part in the circle games of the young, Mari Pärtens had to create her individual performance strategy and roles. Her performances strived for comedy and surprise effects, involved pantomime, physical movement, even acrobatic moves (headstands, somersaults), also acting out men's roles. Mari's masterful parodying and imitation skills are revealed in the descriptions of Marie Sepp about how she tamed an imaginary disobedient horse in "The ploughing game", gave a very truthful imitation of a dog in "Adam's game", etc.

Although undeniably expressing true admiration, Marie Sepp's descriptions disclose some distancing - probably she could not imagine herself in Mari's roles. A good example of the differences in the roles and performativity of the two women is the description of "The gate game":

Two people holding each other's hands are standing in the middle of the room, forming a gate. The group of beggars is behind them, trying to pass through. But they always need to act like beggars. My husband's aunt [Mari Pärtens] made somersaults and headstands, which always made people laugh out loud. I was always in the gate. This is where the singing must start. (ERA II 256, 317/9)

Mari used comical pantomime with appropriate props also outside the circle game situation:

She was a true singer and also played an instrument. Made a violin from a tree burl and played that. She couldn't of course play it, was just 
drawing the bow for the effect. There was no other joker quite like her. She was always a guest at large festivities, where we all laughed so much we thought we're going to break. She also wore a small self-made leather bota bag around her neck, which held only a kortel $l^{24}$ of vodka. When she was mocking around, singing and playing, they poured some vodka into her bota. She used to craft tools, botas, bins, baskets, etc. (ERA II 151, 482/3)

Allegedly Mari sometimes used to wear men's clothes; considering her signature trick headstands, men's trousers must have proved a practical choice at the time when women did not wear underwear (Pärdi 2002: 56-58).

A fine example of switching gender roles and using a rich personal stock of props is the circle game "The glass factory man", which was Mari's solo performance. Mari played the role of a male character, a glass blower, who, depending on the lyrics, blows glass, demonstrates his worn and patched clothes, picks and smokes peat moss instead of tobacco, rejects his old wife, and proposes to young girls:

My aunt was very good at playing. She had a sack around her neck where she held her 'fortune'. There was a bottle that she was blowing, two shirts that she showed around - a grey and a black piece of cloth sewn together I... / Then there was a pipe and mosses that she threw on the ground and then picked up to smoke. Aunt had a self-crafted smoking pipe, which was rather big so that everyone could see. And the wife was also in the sack, a rag doll as they make for children. The betrothal was fun: girls were running like hens from the hawk; boys helped to catch them and got a kiss for each girl. (ETMM, MO 237: 1/35: 83)

The above examples mention the use of men's objects and masculine behaviour. The community members who reminisced about Mari Pärtens did not emphasise the masculinity of Mari's performances. Unlike in the nineteenth-century middle-class culture, there was no need in the agrarian culture to contrast gender-specific behaviour and qualities; also, the sexuality of men and women was viewed in similar terms (Löfström 1998). The exchange of gender roles and imitating the behavioural patterns of the opposite sex has been one of the most common comic devices used in cultural performances. At the same time it had a deeper social and magical meaning, for example, at traditional women's feasts (Hiiemäe 1998: 69-70, 130-131; Kalkun 2010: 21-22; Loorits 1940).

Mari's freedom to use masculine elements in her public performances could be explained with her age: social gerontologists have noticed that in senior years, gender roles tend to become more similar to the opposite gender (Gutmann 1994 [1987]: 155-184; Silver 2003). For women it means more self-centeredness, independence, and being active in the public sphere; sometimes the mascu- 
linity of behaviour has been directly mentioned (Vakimo 2001: 138). But the freedom to shift the boundaries of common behavioural norms is also related to the status of a remarkable creative person in the community, particularly during cultural performances. One must not forget that in the performance arenas connected to regilaul Mari performed as an influential ritual leader, not (only) as a comedian. In any case, the fact that the community accepted and acknowledged Mari Pärtens' performativity is an indication that it fully corresponded to cultural norms.

\section{CONCLUSION}

The analysis of the individual and cultural features of the performances of two late nineteenth-century female singers from central Estonia - Mari Pärtens and Marie Sepp - was inspired by the studies on performativity in the past decades. The main source material, the nearly 500 pages of tradition recorded by Marie Sepp between 1935 and 1940, including biographical information and the spontaneous mediation of subjective experience helps to understand more closely the singer's experience and the reality of the performances. However, the texts were not written down to answer the questions posed in this article. The 'rich fragmentariness' of the sources offers the reader a chance to discover new clues and solutions to them in each reading. This is why the picture of the performativity of the two singers in the late nineteenth-century context is rather sketchy and subjectively interpretative.

The interrelating key factors for shaping the performativity of an outstanding creative person discussed here are:

- a performer's growing-up environment and the changing sociocultural context of his or her singing activities;

- the singer's gender, (the changing) age, and the status of an outstanding creator in the community;

- specific performance situations and arenas with their cultural expectations and opportunities.

The women's growing-up environment must have given them advantages in the development of their creative personality. The homes of Mari Pärtens and Marie Sepp as well as the skills they acquired in childhood differed in the share of the earlier oral tradition and the modern written culture - this was not merely because of the differences in their birth years and the cultural contexts of the period, but probably also due to the type of family, the social status and life course of parents. Both women came from their childhood home with fine 
singing skills, a sense of humour, and the confidence to assume the leading role in public performances. Mari Pärtens inherited a special talent for nonverbal joking from her parental home.

The modernisation process in society and the accompanying changes in performance situations are the factors to be considered in observing the gender and age specifics of the performativity of the two singers as well as their activities as outstanding creative persons of their community.

In the second half of the nineteenth century, the worldview of the rural people began to be influenced by the model based on middle-class romantic love and emotions with new attitudes towards masculinity and femininity. A marriage of love became a new ideal for the youth, one that was not based on economic considerations or controlled by the family. New relationship models were acted out in circle games which were part of youth culture at the time. The bourgeois model of self-control, adopted in the course of modernisation, and avoidance of 'improper' topics and behaviour rendered various aspects of the older singing culture - such as subjects related to sexuality and intimacy (see also Kalkun \& Sarv 2014), but also spontaneous, aggressive and assertive performance practices - inappropriate.

With the changes in society, the importance of the older singing style in community rituals decreased and the singer gradually lost the former influential role of a ritual leader; this applies particularly to wedding rituals. Regarding the fact that at least in the period that we know about the leaders of rituals were mostly older persons, this process could be associated with the general marginalisation of elderly people, which coincides with modernisation - in the conditions of literary culture, old people were no longer the main sources of community knowledge and experience (see, e.g., Sokolovsky 2009: 4-6) and, at the same time, the former family-centred culture was being replaced by the peer group-centred culture.

All the changes that were brought about by modernisation made the performativity of Marie Sepp different from that of Mari Pärtens, whose selfexpression was based more on premodern models. But one must also consider the fact that in the period discussed here these two singers were of different age. Regardless of the type of culture, the culturally acceptable behaviour and areas of activity are different for young women and elderly women past their fertile age. In gerontological research, one of the characteristic features of the behavioural models of the elderly is arguably a shift towards the behaviour of the opposite sex. Evidence about this could be found in special aspects of Mari Pärtens' performances, for example, in her use of the register of verbal duelling, confidence in self-expression, and certain masculine features in behaviour and performances of the newer singing style. 
The situations, and the corresponding performance registers, in turn, determine the mode of the singer's performativity. In some cases, cultural norms could be rather rigid, but even if that is the case, the singer still has sufficient freedom for individual creativity and for testing the limits of the established norms. At the community events related to regilaul, Mari Pärtens was at the forefront as a lead singer at weddings and a leader of calendar rituals, whereas younger Marie Sepp was more active in casual communal work situations. Like Mari Pärtens, Marie Sepp also sang at weddings, but as a young unmarried girl she was not the lead singer, and later on the wedding singing already assumed an entertaining rather than a ritual function.

Marie Sepp's relationship with regilaul was not unambiguous: she preferred the newer singing style, but in some situations she enjoyed singing in the older style and could creatively express herself in both. Referring to AnnaLeena Siikala's work, Lotte Tarkka (2013: 47) has noted that the preserving of the old singing culture could have been a conscious choice for the singers of Viena Karelia. This also seems to apply to Marie Sepp. For the more informed representatives of her generation, regilaul was already part of the prestigious literary culture and national heritage, which deserved to be preserved. This supported Marie in learning songs from the well-known singer Rõõt Meiel as well as from Mari Pärtens. For Marie, an important register of expressing herself in regilaul language - besides performing to folklore collectors - was writing down song texts for the archives.

The performances of circle games, one of the central genres of the newer singing style, reveal the differences in the performativity of the two women particularly clearly. Mari Pärtens found in the circle games of the youth roles suitable for herself to follow her performer's passion and creativity. By doing that she successfully used the privileges of an elderly woman and devices characteristic of premodern performativity - spontaneous and daring ritualcarnivalistic metamorphosis, comical pantomime that rather transgresses limits of restrained modern behaviour, and acrobatics. Participation in the activities of young people and physical activeness as evidence of one's vitality and energy 'uncommon' to one's age characterise several best-known elderly female singers. Mari Pärtens' style of performativity and confidence in self-expression seems to have inspired admiration but also introduced a note of distancing in the writings of Marie Sepp. When playing circle games, Marie herself was more focused on singing; her performance was obviously more 'controlled', and she could play romantic roles as was common to her age.

The main performance arena for Marie Sepp in her older age was sound recording of songs and writing down folklore material for the archives. Since the latter suited Marie's writing inclinations, it gave her a chance to participate 
in modern cultural processes and establish new social contacts, but it was also a sign of the loneliness of a once outstanding performer of oral culture. Unlike Mari Pärtens, she had no young people around to practice the old traditions or play singing games. But in this solitude as a performer, Marie was definitely inspired by knowing that museum worker August Pulst mediated her singing games to the urban youth who practised folk dancing. This served as an alternative to passing on oral tradition in the local community, which was no longer possible in the modernising village environment.

Translated by Kait Tamm

\section{ACKNOWLEDGEMENTS}

I am grateful to Mall Hiiemäe, Tiina Jürgen, Andreas Kalkun, Ene Kuljus, Eda Kalmre, and Lotte Tarkka for their kind help and advice. The research has been supported by the Centre of Excellence in Estonian Studies (CEES, European Regional Development Fund) and is related to research project IUT 22-4 (Estonian Ministry of Education and Research, Estonian Research Council).

\section{NOTES}

1 Marie Sepp's letter (ETMM, MO 237: 1/34: 20).

2 Description of the game "Adam he had seven sons" by Marie Sepp (ETMM, MO 237: 1/35: 92).

3 The characteristic features of the earlier folk song (regilaul, or runo song) are alliteration, parallelism, and a special poetic metre combining syllabic, accentual, and quantitative principles (Estonian version of Kalevala-metre). The newer folk song, which follows European examples, is characterised by end rhyme, stanzaic structure, and syllabic-accentual metre. In Estonia, the newer folk song began to emerge in the eighteenth century. In the second half of the nineteenth century, the earlier regilaul tradition started to give way to the newer folk song and the latter became a prevalent singing style in most parts of Estonia (Rüütel 2012; Sarv 2009; Tedre 2008).

4 The majority of the texts (personal correspondence, life histories, incl. autobiography, recorded tradition) were sent to August Pulst at the Estonian Theatre and Music Museum in 1936-1940 (ETMM, MO 237: 1/34-35). The Estonian Folklore Archives of the Estonian Literary Museum hold 38 pages of manuscripts sent to Eduard Päss in 1935 (ERA II 84, 491/528). In the years 1935 and 1938, Marie Sepp also donated 28 items to the Viljandi Museum. 
5 All these features are more generally characteristic of vernacular literacy, a form of which is recorded tradition (Barton \& Hamilton 2003 [1998]; Kikas 2014; Kuismin \& Driscoll 2013).

6 Johannes Raidla from Rõõt Grauberg, 1936 (ERA II 141, 484/5).

7 Marie Sepp's autobiography (ETMM, MO 237: 1/35: 202).

8 Johannes Raidla from Rõõt Grauberg, 1936 (ERA II 141, 557).

9 Even though Mari was a well-known singer in her community, only 20 of her songs have been recorded in 1906-1910. The folklore collectors had found it unnecessary to record from Mari the songs that they had already recorded from her mother, Rõõt Meiel.

${ }^{10}$ A good example of Marie's wittiness is a comment scribbled next to an ink stain in her written material: "Please forgive me, kind reader, for the Black Sea here, but it can be crossed without a ship or boat, there's nothing to fear." (ETMM MO 237: 1/35: 106) Marie wrote to the President of Estonia on the recommendation of the archive worker August Pulst to restore her rights to use land that had been unlawfully taken from her.

${ }^{11}$ In 1876-1878 folklore collectors wrote down Rõõt's songs extensively. This is why for Marie these songs were also related to the prestigious literary culture. Later on, when performing regilaul to a folklore collector, Marie emphasised that she had learned these from Rõõt Meiel. One could speculate, though, that Rõõt was not the only singer whose example Marie followed: for example, she made a comment to a couple of regilaul texts that she had learned from her mother and grandmother.

12 On the therapeutic function of writing down folklore material see Oras 2010.

13 The concept of the performance register in folklore studies derives from the studies by Dell Hymes (2009) and John Miles Foley $(1992,1995)$. A register is a recurrent language or style of expression related to a certain performance arena (see Foley 1995: 47-56, 79-82). In creating shared meanings, all expressive dimensions of a performance tradition are used, be those linguistic, poetic, musical, situational, bodily, etc. Performance practices, in turn, shape the performance arena that can be understood not only as a space but as a perceived situating frame (Siikala 2000: 258; Kallio 2013: 89; Foley 1995: 47-48). In a broader sense, the concept of register has been used to indicate Kalevala-metric singing as a specific style of expression in general (e.g. Tarkka 2013: 53). Here I am observing register in narrower terms as a style of expression related to specific social situations, an equivalent of which could be a 'local genre' (cf. Kallio 2013).

${ }^{14}$ The first part of the compound Kolga derives from the word kolgas, 'remote corner of land'.

${ }^{15}$ Estonian folklorist Kristi Salve (1989: 30), for example, has emphasised the ritual significance of the physical activity and dancing of the wedding singers.

${ }^{16}$ In the questionnaire the question was about regilaul, the earlier singing style, because the aim was to record the songs of the last singers who could sing regilaul. As to singing 
at communal work, Marie Sepp must have meant singing during harvesting, which was one of the most important and large-scale communal undertakings at the time.

${ }^{17}$ For example, pregnant women were not permitted to sing at weddings (Johannes Raidla from Rõõt Grauberg in 1936 (ERA II 141, 162)). As a further parallel, it could be added that in many premodern cultures various taboos are related to female fertility and only after the fertile period women can get the status of ritual leaders (Apo 1995, 1998; Vakimo 2001: 133-134).

${ }^{18}$ In Kolga-Jaani, singing was most common during communal rye and flax harvesting.

19 The ritual of fertility magic of finishing work in the field is associated with singing a specific song ("Finish, finish, precious field!").

${ }^{20}$ One of the most important features of verbal duelling is the heightened level of energy and a special state of mind which is experienced not only by the battling singers but by everyone present (Anttonen 1987: 97; Pagliai 2009; Sykäri 2014: 110).

${ }^{21}$ The 1880s was the period when the ideas of the temperance movement spread among rural people and temperance societies were established in Estonia (Talve 2005 [2004]: 387; Jansen 2007: 342-345). The Kolga-Jaani temperance society Eesmärk ('The Purpose') was founded in 1890 .

${ }^{22}$ The text of this universal ballad speaks of a young man leaving the country, upon which her girlfriend dies of sorrow. After returning and witnessing what has happened, the young man also dies, "holding his loved one in his arms"; both are taken to the monastery, are clad in white, and then carried to the graveyard.

${ }^{23}$ A maiden accuses the young man for leaving her and finding a new bride, for taking flowers and apples from the maiden's garden. This is followed by a generalisation: men are not to be trusted, they all cheat (ETMM, MO 237: 1/35: 98).

${ }^{24}$ A kortel (equalled 0.3 litres) was a measure of vodka used in Estonian taverns in the eighteenth and nineteenth centuries.

\section{ARCHIVAL SOURCES}

ETMM, MO - Estonian Theatre and Music Museum, collection of music organisations ERA - manuscript collection of the Estonian Folklore Archives at the Estonian Folklore Archives, Estonian Literary Museum

EKS - manuscript collection of the Estonian Literary Society at the Estonian Folklore Archives, Estonian Literary Museum 


\section{REFERENCES}

Abu-Lughod, Lila 1991. Writing against Culture. In: Richard G. Fox (ed.) Recapturing Anthropology: Working in the Present. Santa Fe, NM: School of American Research Press, pp. 137-162.

Abu-Lughod, Lila 1999. Preface to the Second Edition. In: Veiled Sentiments: Honor and Poetry in a Bedouin Society. Updated Edition with a New Preface. Berkeley \& Los Angeles \& London: University of California Press, pp. xi-xxx.

Anepaio, Terje 1996. Laat - see ilmarahva pulm. Tartu linna ja maakonna laadad 1920-1940. [Fairs in Tartu and Tartu County in 1920-1940.] Studia Ethnologica 2. Tartu: Atlex.

Anttonen, Pertti 1987. Rituaalinen pilkka länsi-inkeriläisissä kylähäissä. [Ritual Mockery in the Village Weddings of Western Ingria.] Diss. (MA Thesis). Unpublished manuscript. Department of Folklore Studies, University of Helsinki.

Apo, Satu 1995. Naisen väki: Tutkimuksia suomalaisten kansanomaisesta kulttuurista ja ajattelusta. [Woman's Power: Studies about Finnish Traditional Culture and Mentality.] Helsinki: Hanki ja Jää.

Apo, Satu 1998. "Ex Cunno Come the Folk and Force": Concepts of Women's Dynamistic Power in Finnish-Karelian Tradition. In: Satu Apo \& Aili Nenola \& Laura StarkArola (eds.) Gender and Folklore: Perspectives on Finnish and Karelian Culture. Studia Fennica Folkloristica 4. Helsinki: Finnish Literature Society, pp. 63-91.

Asplund, Anneli 2002. Changing Attitudes to Love in Finnish Folk Songs. In: AnnaLeena Siikala (ed.) Myth and Mentality: Studies in Folklore and Popular Thought. Studia Fennica Folkloristica 8. Helsinki: Finnish Literature Society, pp. 233-246.

Asplund, Anneli 2006. Runolaulusta rekilauluun. [From Runo Song to Newer Folk Song.] In: Anneli Asplund \& Petri Hoppu \& Heikki Laitinen \& Timo Leisiö \& Hannu Saha \& Simo Westerholm (eds.) Suomen musiikin historia 8: Kansanmusiikki. [History of Finnish Music 8: Folk Music.] Helsinki: Werner Söderström, pp. 108-159.

Barton, David \& Hamilton, Mary 2003 [1998]. Local Literacies: Reading and Writing in One Community. London \& New York: Routledge.

Bauman, Richard 1992. Performance. In: Richard Bauman (ed.) Folklore, Cultural Performances, and Popular Entertainments: A Communications-Centered Handbook. New York \& Oxford: Oxford University Press, pp. 41-49.

Bauman, Richard 2012. Performance. In: Regina F. Bendix \& Galit Hasan-Rokem (eds.) A Companion to Folklore. Oxford: Wiley-Blackwell, pp. 94-118.

Burke, Peter (ed.) 1991. New Perspectives on Historical Writing. Cambridge: Polity Press.

Butler, Judith 1990. Gender Trouble: Feminism and the Subversion of Identity. London: Routledge.

Butler, Judith 1993. Bodies That Matter: On the Discursive Limits of 'Sex'. New York \& London: Routledge.

Cashman, Ray \& Mould, Tom \& Shukla, Pravina 2011. Introduction: The Individual and Tradition. In: Ray Cashman \& Tom Mould \& Pravina Shukla (eds.) The Individual and Tradition: Folkloristic Perspectives. Bloomington \& Indianapolis: Indiana University Press, pp. 1-26. 
EKA 1966 = Eesti kirjanduse ajalugu II. XIX sajandi teine pool. [History of Estonian Literature II. Second Half of the 19th Century.] Edited by Endel Nirk. Tallinn: Eesti Raamat.

Fabian, Johannes 2001. Anthropology with an Attitude. Critical Essays. Stanford, CA: Stanford University Press.

Foley, John Miles 1992. Word-Power, Performance, and Tradition. The Journal of American Folklore, Vol. 105, No. 417, pp. 275-301. http://dx.doi.org/10.2307/541757.

Foley, John Miles 1995. The Singer of Tales in Performance. Bloomington \& Indianapolis: Indiana University Press.

Friedman, Susan Stanford 2002. "Border Talk", Hybridity, and Performativity: Cultural Theory and Identity in the Spaces between Difference. Eurozine. Available at http://www.eurozine.com/pdf/2002-06-07-friedman-en.pdf, last accessed on January 12, 2017.

Frykman Jonas \& Löfgren, Orvar 2003 [1987]. Culture Builders: A Historical Anthropology of Middle-Class Life. Transl. by Alan Grozier. New Brunswick, NJ \& London: Rutgers University Press.

Giddens, Anthony 1992. The Transformation of Intimacy: Sexuality, Love, and Eroticism in Modern Societies. Stanford: Stanford University Press.

Glassie, Henry 2003. Tradition. In: Burt Feintuch (ed.) Eight Words for the Study of Expressive Culture. Urbana \& Chicago: University of Illinois Press, pp. 176-197.

Gutmann, David 1994 [1987]. Reclaimed Powers: Toward a New Psychology of Men and Women in Later Life. Evanston: Northwestern University Press.

Hellier, Ruth 2013. Introduction. Vocal Herstories: Resonances of Singing, Individuals and Authors. In: Ruth Hellier (ed.) Women Singers in Global Contexts: Music, Biography, Identity. Urbana: University of Illinois Press, pp. 1-37.

Hiiemäe, Mall 1998. Der estnische Volkskalender. FFC No. 268. Helsinki: Suomalainen Tiedeakatemia.

Hurt, Jakob 1886. Vana Kannel. Alte Harfe. Täieline kogu vanu Eesti rahvalauluzid. Tõine kogu. [The Old Psaltery: Complete Collection of Old Estonian Folk Songs.] Tartu: C. Mattiesen.

Hymes, Dell 2009 [1989]. Ways of Speaking. In: Alessandro Duranti (ed.) Linguistic Anthropology: A Reader. 2nd edition. Malden, MA \& Oxford: Wiley-Blackwell, pp. 158-171.

Jackson, Michael 1996. Introduction: Phenomenology, Radical Empiricism, and Anthropological Critique. In: Michael Jackson (ed.) Things as They Are: New Directions in Phenomenological Anthropology. Bloomington \& Indianapolis: Indiana University Press, pp. 1-50.

Jackson, Michael 2005. Preface: The Struggle for Being. In: Existential Anthropology: Events, Exigencies and Effects. Methodology and History in Anthropology, Vol. 11. New York \& Oxford: Berghahn Books, pp. ix-xxxii.

Jansen, Ea 2004. Vaateid eesti rahvusluse sünniaegadesse. [Views of the Birth of Estonian Nationalism.] Tartu: Ilmamaa.

Jansen, Ea 2007. Eestlane muutuvas ajas: Seisusühiskonnast kodanikuühiskonda. [Estonians in a Changing World: From Status Society to Civil Society.] Tartu: Eesti Ajalooarhiiv. 
Kalkun, Andreas 2010. Naiselikkus, mehelikkus ja seksuaalsus talupojakultuuris. [Femininity, Masculinity and Sexuality in the Peasant Culture.] In: Brigitta Davidjants (ed.) Kapiuksed valla: arutlusi homo-, bi- ja transseksuaalsusest. Tallinn: Eesti Gei Noored, pp. 12-22. Available at https://oef.org.ee/fileadmin/ media/valjaanded/v2ljaanded/Kapiuksed_valla.pdf, last accessed on January 12, 2017.

Kalkun, Andreas \& Sarv, Mari 2014. Seks ja poeesia: regilaulu peidus pool. [Sex and Poetry: The Hidden Side of Regilaul.] Vikerkaar, No. 4-5, pp. 91-108. Available at http://www.digar.ee/arhiiv/et/perioodika/35039, last accessed on January 12, 2017.

Kallio, Kati 2013. Laulamisen tapoja: esitysareena, rekisteri ja paikallinen laji LänsiInkeriläisessä kalevalamittaisessa runossa. [Ways of Singing: Performance Arena, Register and Local Genre in West-Ingrian Oral Poetry.] Helsinki: Helsingin yliopisto.

Kikas, Katre 2014. Folklore Collecting as Vernacular Literacy: Establishing a Social Position for Writing in the 1890s Estonia. In: Ann-Catrine Edlund \& Lars-Erik Edlund \& Susanne Haugen (eds.) Vernacular Literacies - Past, Present and Future. Umeå: Umeå University \& Royal Skyttean Society, pp. 309-323.

Kuismin, Anna \& Driscoll, Matthew James (eds.) 2013. White Field, Black Seeds: Nordic Literacy Practices in the Long Nineteenth Century. Studia Fennica Litteraria 7. Helsinki: Finnish Literature Society.

Kurki, Tuulikki 2004. Marginality and Reflexivity in Folklore Studies. In: Anna-Leena Siikala \& Barbro Klein \& Stein R. Mathisen (eds.) Creating Diversities: Folklore, Religion and the Politics of Heritage. Studia Fennica Folkloristica 14. Helsinki: Finnish Literature Society, pp. 260-276.

Löfström, Jan 1998. Changing Conceptions of Gender Polarity in Finland: From Rural to Urban Culture. In: Satu Apo \& Aili Nenola \& Laura Stark-Arola (eds.) Gender and Folklore: Perspectives on Finnish and Karelian Culture. Studia Fennica Folkloristica 4. Helsinki: Finnish Literature Society, pp. 239-259.

Loorits, Oskar 1940. Das sog: Weiberfest bei den Russen und Setukesen in Estland. Eesti Rahvaluule Arhiivi toimetused, Vol. 14. Tartu: K. Mattiesen.

Mikkola, Kati 2009. Tulevaisuutta vastaan: Uutuuksien vastustus, kansantiedon keruu ja kansakunnan rakentaminen. [Against the Future: Resistance to Innovation, Collection of Folk Knowledge and Nation Building.] Suomalaisen Kirjallisuuden Seuran toimituksia 1251. Helsinki: Suomalaisen Kirjallisuuden Seura.

Mikkola, Kati 2013. Self-Taught Collectors of Folklore and Their Challenge to Archival Authority. In: Anna Kuismin \& Matthew James Driscoll (eds.) White Field, Black Seeds: Nordic Literacy Practices in the Long Nineteenth Century. Studia Fennica Litteraria 7. Helsinki: Finnish Literature Society, pp. 146-157.

Niiranen, Elina 2013. Maria Feodorovan laulupolut. Vienankarjalaisen kansanlaulajan repertuaari musiikkisukupolven rakentajana. [Maria Feodorova's Songpathways. Songrepertoire of Viena Karelian Singer Constructing Local Musical Generation.] Acta Universitatis Tamperensis 1836. Tampere: Tampere University Press. Available at https://tampub.uta.fi/handle/10024/68221, last accessed on January 12, 2017. 
Norrick, Neal R. 2004. Non-Verbal Humor and Joke Performance. Humor - International Journal of Humor Research, Vol. 17, No. 4, pp. 401-409. http://dx.doi.org/10.1515/ humr.2004.17.4.401.

North, Michael 2015. Nordic Romanticism. In: Michael North, The Baltic: A History. Transl. by Kenneth Kronenberg. Cambridge \& London: Harvard University Press, pp. 183-221.

Oras, Janika 2008. Viie 20. sajandi naise regilaulumaailm: Arhiivitekstid, kogemused ja mälestused. [The Regilaul World of Five 20th Century Women: Archival Texts, Experiences and Memories.] Eesti Rahvaluule Arhiivi toimetused 27. Tartu: Eesti Kirjandusmuuseumi Teaduskirjastus. Available at http://www.ema.edu. ee/vaitekirjad/doktor/Janika_Oras.pdf, last accessed on January 12, 2017.

Oras, Janika 2010. Motivations of Volunteer Archive Correspondents: Three Women from Estonia. Ethnologia Fennica: Finnish Studies in Ethnology, No. 37, pp. 22-36. Available at http://www.academia.edu/16865525/Motivations_of_ Volunteer_Archive_Correspondents_Three_Women_from_Estonia, last accessed on January 12, 2017.

Ounapuu, Piret 2003. Eesti pulm. [The Estonian Wedding.] Tallinn: Tänapäev.

Pagliai, Valentina 2009. The Art of Dueling with Words: Toward a New Understanding of Verbal Duels across the World. Oral Tradition, Vol. 24, No. 1, pp. 61-88. DOI: $10.1353 /$ ort.0.0054.

Pärdi, Heiki 2002. "Loomulike vajaduste" rahuldamise viisid Eestis 20. sajandi algupoolel. [The Ways of "Getting Relief" in Estonia in the First Half of the 20th Century.] In: Terje Anepaio \& Tuuli Kaalep \& Toivo Sikka (eds.) Eesti Rahva Muuseumi Aastaraamat 46. Tartu: Eesti Rahva Muuseum, pp. 51-79.

Phelan, Peggy 1993. Unmarked: The Politics of Performance. London: Routledge.

Roca, Jordi \& Enguix, Begonya 2015. Introduction: Love and Its Transformations. In: Begonya Enguix \& Jordi Roca (eds.) Rethinking Romantic Love: Discussions, Imaginaries and Practices. Newcastle upon Tyne: Cambridge Scholars Publishing, pp. 1-24.

Ruskin, Jesse D. \& Rice, Timothy 2012. The Individual in Musical Ethnography. Ethnomusicology, Vol. 56, No. 2, pp. 299-323. http://dx.doi.org/10.5406/ ethnomusicology.56.2.0299.

Rüütel, Ingrid 1980. Eesti uuemad laulumängud I. [Estonian Newer Song Games I.] Tallinn: Eesti Raamat.

Rüütel, Ingrid 2012. Eesti uuema rahvalaulu kujunemine. [The Formation of Estonian Newer Folk Song.] Tartu: Eesti Kirjandusmuuseumi Teaduskirjastus.

Salve, Kristi 1989. Põhja-Tartumaa töö- ja tavandilaulud. [Working and Ritual Songs from Northern Tartumaa.] In: Kristi Salve \& Ingrid Rüütel. Põhja-Tartumaa regilaulud 1: Töö-ja tavandilaulud. [Regilaul Songs from Northern Tartumaa 1: Working and Ritual Songs.] Tallinn: Eesti NSV Teaduste Akadeemia, pp. 8-37.

Sarmela, Matti 1974. Folklore, Ecology and Superstructures. Studia Fennica, Vol. 18, pp. 76-115. Available at http://www.kotikone.fi/matti.sarmela/ecofolklore. htm\#Matti_Sarmela, last accessed on January 13, 2017.

Sarv, Mari 2009. Stichic and Stanzaic Poetic Form in Estonian Tradition and in Europe. Traditiones, Vol. 38, No. 1, pp. 161-171. http://dx.doi.org/10.3986/ Traditio2009380111. 
Schechner, Richard 1988. Performance Theory. 2nd revised edition. London: Routledge. Siikala, Anna-Leena 2000. Body, Performance, and Agency in Kalevala Rune-Singing. Oral Tradition, Vol. 15, No. 2, pp. 255-278. Available at http://journal.oraltradition. org/files/articles/15ii/5_siikala.pdf, last accessed on January 13, 2017.

Silver, Catherine B. 2003. Gendered Identities in Old Age: Toward (De)gendering? In: Journal of Aging Studies, Vol. 17, No. 4, pp. 379-397. http://dx.doi.org/10.1016/ S0890-4065(03)00059-8.

Smith, Sidonie \& Watson, Julia 2001. Reading Autobiography: A Guide for Interpreting Life Narratives. Minneapolis \& London: University of Minnesota Press.

Soikkeli, Markku 1999. Rakkauskoodiston vakiintuminen Euroopassa 1600-1900-luvulla. [Development of Love Codes in Europe in the 1600s-1900s.] In: Sari Näre (ed.) Tunteiden sosiologiaa I: Elämyksiä ja läheisyyttä. [Sociology of Feelings I: Experiences and Proximity.] Tietolipas 156. Helsinki: Suomalaisen Kirjallisuuden Seura, pp. 19-35.

Sokolovsky, Jay 2009. [Introduction to] Part I. A Global Vision of Aging, Culture and Context. In: Jay Sokolovsky (ed.) The Cultural Context of Aging: Worldwide Perspectives. 3rd edition. Westport \& London: Praeger, pp. 1-12.

Spiller, Henry 2010. Erotic Triangles: Sundanese Dance and Masculinity in West Java. University of Chicago Press.

Spiller, Henry 2014. Interdisciplinarity and Musical Exceptionalism. Ethnomusicology, Vol. 58, No. 2, pp. 341-346. http://dx.doi.org/10.5406/ethnomusicology.58.2.0341.

Sykäri, Venla 2014. Kilpaa laulava yhteisö. [Creating Communities with Song Competitions.] In: Janika Oras \& Andreas Kalkun \& Mari Sarv (eds.) Regilaulu kohanemine ja kohandajad. [Adaptation and Adapters of Regilaul.] Eesti Rahvaluule Arhiivi toimetused 31. Tartu: Eesti Kirjandusmuuseumi Teaduskirjastus, pp. 109-136.

Talve, Ilmar 2005 [2004]. Eesti kultuurilugu. Keskaja algusest Eesti iseseisvuseni. [Estonian Cultural History.] Tartu: Ilmamaa.

Tampere, Herbert 1956. Mõningaid eestlaste etnilise ajaloo küsimusi suulise rahvaloomingu valgusel. [Some Problems of Estonians' Ethnic History in the Light of Oral Tradition.] In: H. Moora (ed.) Eesti rahva etnilisest ajaloost. [On the Ethnic History of Estonians.] Tallinn: Eesti Riiklik Kirjastus, pp. 255-277.

Tampere, Herbert 1976. Rahvaluulest Chr. H. J. Schlegeli reisilt Eestimaale 1807. aastal. [About Folklore from the Travel of Chr. H. J. Schlegel to Estonia in 1807.] Emakeele Seltsi Aastaraamat 21, 1975. Tallinn: Teaduste Akadeemia Kirjastus, pp. 105-123.

Tampere, Herbert 1999. Eesti rahvaviiside antoloogia I. [Anthology of Estonian Folk Melodies I.] Tallinn: Eesti Keele Instituut.

Tarkka, Lotte 2005. Rajarahvaan laulu. Tutkimus Vuokkiniemen kalevalamittaisesta runokulttuurista 1821-1921. [Songs of the Border People: The Kalevala-Metre Poetry in Vuokkiniemi Parish 1821-1921.] Suomalaisen Kirjallisuuden Seuran Toimituksia 1033. Helsinki: Suomalaisen Kirjallisuuden Seura.

Tarkka, Lotte 2013. Songs of the Border People: Genre, Reflexivity, and Performance in Karelian Oral Poetry. Transl. by Leila Virtanen. FFC No. 305. Helsinki: Suomalainen Tiedeakatemia. 
Tedre, Ülo 1973. Eesti pulmad: Lühiülevaade muistsetest kosja-ja pulmakommetest. [Estonian Wedding.] Tallinn: Eesti Raamat.

Tedre, Ülo 2008. Rahvaluule. [Folklore.] In: Ants Viires \& Elle Vunder (eds.) Eesti rahvakultuur. [Estonian Folk Culture.] Tallinn: Eesti Entsüklopeediakirjastus, pp. 423-448.

Timonen, Senni 2004. Minä, tila, tunne: Näkökulmia kalevalamittaisen kansanlyriikkaan. [Self, Space, and Emotion: Aspects of Kalevala-Metre Folk Lyric.] Suomalaisen Kirjallisuuden Seuran Toimituksia 963. Helsinki: Suomalaisen Kirjallisuuden Seura.

Vakimo, Sinikka 2001. Paljon kokeva, vähän näkyvä: Tutkimus vanhaa naista koskevista kulttuurisista käsityksistä ja vanhan naisen elämänkäytännöistä. [Out of Sight but Full of Life: A Study of Cultural Conceptions of Old Women and Their Life Practices.] Suomalaisen Kirjallisuuden Seuran Toimituksia 818. Helsinki: Suomalaisen Kirjallisuuden Seura.

Valk, Ülo 2004. On the Discursive Foundations of Estonian Folkloristics: A Farmer's Field of Vision. In: Ene Kõresaar \& Art Leete (eds.) Everyday Life and Cultural Patterns: International Festschrift for Elle Vunder. Studies in Folk Culture, Vol. 3. Tartu: Tartu University Press, pp. 265-272. Available at http://dspace.ut.ee/ handle/10062/54547, last accessed on January 16, 2017.

Valk, Ülo 2014. The Folk and Others: Constructing Social Reality in Estonian Legends. In: Valter Lang \& Kalevi Kull (eds.) Estonian Approaches to Culture Theory: Approaches to Culture Theory 4. Tartu: University of Tartu Press, pp. 222-239. Available at http://www.digar.ee/arhiiv/en/books/62304, last accessed on January 16, 2017.

Vilkko, Anni 1997. Omaelämäkerta kohtaamispaikkana: Naisen elämän kerronta ja luenta. [Autobiography as a Meeting Place: Narrating and Reading of Woman's Life.] Suomalaisen Kirjallisuuden Seuran Toimituksia 663. Tampere: Suomalaisen Kirjallisuuden Seura.

Vunder, Elle 2001. Modernization and Changes in Cultural Patterns in 19th-20th Century Estonia. In: Pirjo Korkiakangas \& Elina Kiuru (eds.) An Adventurer in European Ethnology. Jyväskylä: Atena, pp. 129-154.

Vunder, Elle 2008. Moderniseerumine ja kultuurimustrite muutused 19. sajandi teisel poolel ja 20. sajandil. [Modernisation and Changes in Cultural Patterns in the Second Half of the 19th and in the 20th Century.] In: Ants Viires \& Elle Vunder (eds.) Eesti rahvakultuur. [Estonian Folk Culture.] Tallinn: Eesti Entsüklopeediakirjastus, pp. 459-475.

Janika Oras is senior research fellow at the Estonian Folklore Archives of the Estonian Literary Museum, Estonia, and teaches traditional singing at the Estonian Academy of Music and Theatre.

janika@folklore.ee 